DOI: https://doi.org/10.6036/PDCP

\section{Publicaciones DYNA CrossMark Policy}

CrossMark is a multi-publisher initiative to provide a standard way for readers to locate the authoritative version of an article or other published content. By applying the CrossMark logo, Publicaciones DYNA is committing to maintaining the content it publishes and to alerting readers to changes if and when they occur.

Clicking the CrossMark logo on a document will tell you its current status and may also give you additional publication-record information about the document.

For more information on CrossMark, please visit the CrossMark site.

For general author guidelines and information, please see: Author's guidelines.

\section{Correction and Retraction Policies}

Publicaciones DYNA is committed to uphold the integrity of the literature and publishes Errata, Expressions of Concerns or Retraction Notices dependent on the situation and in accordance with the COPE Retraction Guidelines. In all cases, these notices are linked to the original article.

Publicaciones DYNA follows the guidelines set by COPE in Retraction guidelines

\section{Política CrossMark de Publicaciones DYNA}

CrossMark es una iniciativa de varios editores para proporcionar una forma estándar para que los lectores localicen la versión actualizada de un artículo u otro contenido publicado. Al aplicar el logotipo de CrossMark, Publicaciones DYNA se compromete a mantener actualizado el contenido que publica y a avisar a los lectores de los cambios que se produzcan.

Al hacer clic en el logotipo de CrossMark sobre un documento, se le indicará su estado actual y también podrá obtener información adicional sobre el registro de la publicación.

Para más información sobre CrossMark, visite el sitio web de CrossMark.

Para obtener información y directrices generales sobre los autores, consulte: Directrices para autores.

\section{Políticas de corrección y retractación}

Publicaciones DYNA se compromete a mantener la integridad de la literatura y publicará Erratas, Expresiones de Preocupación o Avisos de Retracción dependiendo de la situación y de acuerdo a las Directrices de Retracción de COPE. En todos los casos, estos avisos están vinculados al artículo original.

Publicaciones DYNA sigue las directrices establecidas por COPE en lo referente a Directrices de retracción 